\title{
Growth curve of free-ranging Trichechus inunguis
}

\author{
Jociery Einhardt Vergara-Parente ${ }^{1,2,4,8}$, Cristiano Leite Parente ${ }^{3}$, Miriam Marmontel ${ }^{4}$, \\ Jean Carlos Ramos Silva ${ }^{5,6}$ \& Fabrício Bezerra Sá ${ }^{7}$ \\ ${ }^{1}$ Programa de Pós-graduação em Ciência Veterinária, \\ Universidade Federal Rural de Pernambuco - UFRPE, Rua Dom Manoel de Medeiros, s/n, \\ Dois Irmãos, CEP 52171-900, Recife, PE, http://www.ufrpe.br \\ ${ }^{2}$ Fundação Mamíferos Aquáticos - FMA, http://www.mamiferosaquaticos.org.br \\ ${ }^{3}$ Petróleo Brasileiro S.A., http:// www.petrobras.com.br \\ ${ }^{4}$ Grupo de Pesquisas em Mamíferos Aquáticos Amazônicos, \\ Instituto de Desenvolvimento Sustentável Mamirauá, http:// www.mamiraua.org.br \\ ${ }^{5}$ Departamento de Medicina Veterinária, \\ Universidade Federal Rural de Pernambuco - UFRPE, http://www.ufrpe.br \\ ${ }^{6}$ Instituto Brasileiro para Medicina da Conservação - Tríade, http://www.triade.org.br \\ ${ }^{7}$ Departamento de Morfologia e Fisiologia Animal, \\ Universidade Federal Rural de Pernambuco - UFRPE, http://www.ufrpe.br \\ ${ }^{8}$ Corresponding author: Jociery Einhardt Vergara-Parente, e-mail: jociery.parente@ gmail.com
}

VERGARA-PARENTE, J.E., PARENTE, C.L., MARMONTEL, M., SILVA, J.C.R. \& SÁ, F.B. Growth curve of free-ranging Trichechus inunguis. Biota Neotrop. 10(3): http://www.biotaneotropica.org.br/v10n3/en/ abstract?article+bn01410032010.

\begin{abstract}
The objective of this work was to describe growth curves for free-ranging Amazonian manatees in Brazil. Data analyzed included age estimates and biometrics from 60 Amazonian manatees (33 males and 27 females) captured between 1993 and 2006 by local residents of the mid-Solimões and Pirativa Rivers, in Amazonia, and collected by the Instituto de Desenvolvimento Sustentável Mamirauá and Centro Nacional de Conservação e Manejo de Mamíferos Aquáticos/ICMBio. The non-linear mathematical model used to analyze the data was the von Bertalanffy's equation; two growth curves were calculated, one for males $\mathrm{L}(\mathrm{t})_{\text {male }}=299.4\left[1-\mathrm{e}^{-0.0897507(t+6.55696)}\right]$, and one for females $\mathrm{L}(\mathrm{t})_{\text {female }}=256.1\left[1-\mathrm{e}^{-0.23731(\mathrm{t}+3.01921)}\right]$. Based on these equations, length at birth for the Amazonian manatee is estimated at $133.2 \mathrm{~cm}$ (average $=113.0 \mathrm{~cm} ; \mathrm{SD}=34.4 \mathrm{~cm}$ ) for males, and $131.0 \mathrm{~cm}$ (average $=124.7 \mathrm{~cm} ; \mathrm{SD}=22.0 \mathrm{~cm}$ ) for females. Among the males, the annual growth rate was $0.09 \mathrm{~cm}(95 \%$ CI: \pm 0.002$)$, with a maximum length of $299.4 \mathrm{~cm}(95 \% \mathrm{CI}: \pm 2.039)$, while females presented a growth rate of $0.24 \mathrm{~cm}$ per year $(95 \% \mathrm{CI}: \pm 0.004)$, reaching up to $256.1 \mathrm{~cm}(95 \% \mathrm{CI}: \pm 0.4832)$ of total length. Even though von Bertalanffy's equation is not commonly used for sirenians, and considering that when previously applied it did not obtain satisfactory results, in this study it proved adequate for the establishment of the growth curve for free-ranging Amazonian manatees.
\end{abstract}

Keywords: Amazonian manatee, age estimate, von Bertalanffy, sirenians.

VERGARA-PARENTE, J.E., PARENTE, C.L., MARMONTEL, M., SILVA, J.C.R. \& SÁ, F.B. Curva de crescimento Trichechus inunguis de vida livre. Biota Neotrop. 10(3): http://www.biotaneotropica.org.br/v10n3/ pt/abstract?article+bn01410032010.

Resumo: O objetivo deste trabalho foi descrever curvas de crescimento para peixes-boi-da-Amazônia de vida livre no Brasil. Foram utilizados dados etários e biométricos de 60 peixes-boi-da-Amazônia, 33 machos e 27 fêmeas, capturados entre 1993 e 2006 por pessoas ribeirinhas do médio Solimões e do Rio Pirativa, na região Amazônica, oriundos do Instituto de Desenvolvimento Sustentável Mamirauá e do Centro Nacional de Conservação e Manejo de Mamíferos Aquáticos/ICMBio. O modelo matemático não-linear utilizado para análise desses dados foi a equação derivada de von Bertalanffy, sendo calculadas duas equações de crescimento, uma para os machos $\mathrm{L}(\mathrm{t})_{\text {macho }}=299,4\left[1-\mathrm{e}^{-0,0897507(t+6,55696)}\right]$, e outra para as fêmeas $\mathrm{L}(\mathrm{t})_{\text {fềmea }}=256,1\left[1-\mathrm{e}^{-0,23731(\mathrm{t}+3,01921)}\right]$. Com o desenvolvimento dessas equações, o comprimento do peixe-boi-da-Amazônia ao nascer foi de $133,2 \mathrm{~cm}$ (média =113,0 cm; $\mathrm{SD}=34,4 \mathrm{~cm}$ ) quando macho, e 131,0 cm (média = 124,7 cm; $\mathrm{SD}=22,0 \mathrm{~cm}$ ) quando fêmeas. Nos machos a taxa de crescimento anual obtida foi de 0,09 $\mathrm{cm}$ (IC 95\%: $\pm 0,002$ ), atingindo uma envergadura máxima de 299,4 cm (IC 95\%: $\pm 2,039$ ), enquanto as fêmeas apresentaram uma taxa de crescimento de 0,24 cm ao ano (IC 95\%: \pm 0,004), podendo alcançar até $256,1 \mathrm{~cm}$ (IC 95\%: $\pm 0,4832$ ) de envergadura. Apesar da equação de von Bertalanffy não ser comumente utilizada para sirênios, e quando aplicada anteriormente não ter obtido resultados satisfatórios, neste estudo apresentou-se adequada para a elaboração da curva de crescimento para peixe-boi-da-Amazônia de vida livre.

Palavras-chave: peixe-boi-da Amazônia, estimativa de idade, von Bertalanffy, sirênios. 


\section{Introduction}

Trichechus inunguis, commonly known as the Amazonian manatee, is endemic to the Amazon basin, and has been recorded in Brazil, Colombia, Peru and Ecuador (Husar 1977). It is the smallest representative of the Trichechidae family, with specimens reaching up to $3 \mathrm{~m}$ of total length, and weighing up to $450 \mathrm{~kg}$ (Rosas 1994). Skin color is dark gray to black, usually with white patches on the ventral region and absence of nails on the pectoral fins. It feeds, essentially, on aquatic and semi-aquatic plants, consuming up to $10 \%$ of its body weight in plants daily (Colares 1991).

In Brazil, the hunting pressure over the Amazonian manatee, was initially characterized for commercial purposes and, nowadays, although less intense, it still exists mainly for subsistence and illegal meat trade (Rosas 1994). The species is classified as "vulnerable" by the Red List of Threatened Species of IUCN (IUCN 2009) and as "threatened of extinction" by the Action Plan for Aquatic Mammals in Brazil (IBAMA 2001).

Despite this threatened condition, there are still gaps in the biological knowledge of the species. The description of growth curves are among the fundamental research to be conducted in order to advance with the knowledge on the species. Growth curves help in studies related to sexual characteristics, as well as in the evaluation of growth rates and size at sexual maturity. Best et al. (1982) were the first to derive a growth curve for the first years of Amazonian manatee specimens in captivity. Colares (2002) studied non-linear growth models for the species, also using length information from captive species. Considering that the diet offered and the management implemented may affect the characteristics of animal growth (Colares 2002, Albuquerque Jr. 2003), there may be some difference between growth equations for captive versus wild animals.

Several non-linear models have been proposed to describe growth curves, and the most often used are Brody's, von Bertalanffy's, Logistic and Gompertz's (see Fitzhugh Jr. 1976). Colares (2002) evaluated all four models for captive Amazonian manatees. However he only produced parameters for Gompertz's and Brody's models. Therefore, the goal of this article was to apply von Bertalanffy's equation to describe growth curves for wild males and females Amazonian manatees in Brazil.

\section{Material and Methods}

Sample consisted of biometric information and tympanic bones from 60 Amazonian manatees ( 33 males and 27 females) captured between 1993 and 2006 by local residents of the mid Solimões and Pirativa Rivers, in the Brazilian Amazonia. Those data and the biological material were deposited in the aquatic mammal laboratory of Instituto de Desenvolvimento Sustentável Mamirauá and Centro Nacional de Conservação e Manejo de Mamíferos Aquáticos/ ICMBio.

The age of carcasses was estimated through demineralization of bony tissues from the tympanic dome, and preparation of stained thin sections for microscopic counting of groups of growth layers (Marmontel et al. 1990). Curvilinear length of carcasses from CMA/ ICMBio were given in centimeters, whereas biometric data from IDSM were submitted to conversion from "palmos" to centimeters $(21.71 \mathrm{~cm})$ (J.E. Vergara-Parente et al., unpublished.)

Studies of this nature tend to use the rectilinear length as a growth parameter, considering that the curvilinear length varies with the animals' health (Rosas 1994). However, the use of rectilinear length is not common among the local residents, which frequently use "palmos" as a measure standard. Wherefore, considering that data of growth curves for Amazonian manatee are scarce, we decided to use the curvilinear length as a parameter, and assume any possible error present in this measurement methodology.
The non-linear mathematical model used was von Bertalanffy's derived equation: $\mathrm{L}(\mathrm{t})=\mathrm{L} \infty\left[1-\mathrm{e}^{-\mathrm{k}(\mathrm{t}-\mathrm{t})}\right]$, where 1 is the length at a time $t$, $L \infty$ (also called infinite $L$ ) is the asymptotic length where growth is zero, and $k$ is the growth rate. The $t_{0}$ parameter corresponds to the age at which the organism presents length at birth. Parameters $k, L \infty$ e $t_{0}$ were estimated by means of non-linear regressions. Two growth equations were calculated, one for each sex.

\section{Results}

Male Amazonian manatees presented a total curvilinear length between 87 and $282 \mathrm{~cm}$ (mean $=210.9 \mathrm{~cm}$; $\mathrm{sd}=51.9 \mathrm{~cm})$ with ages estimated between 0 and 30 years (mean $=7$ years, $\mathrm{sd}=8$ years). Values of total curvilinear length for females were greater than for males, averaging between 110 and $290 \mathrm{~cm}$ (mean $=213.7 \mathrm{~cm}$, $\mathrm{sd}=47.6 \mathrm{~cm})$, with ages estimated between 0 and 36 years (mean $=8$ years, $\mathrm{sd}=8$ years).

According to van Bertalanffy's model, the growth equation that best described the curve for males was $\mathrm{L}(\mathrm{t})_{\text {male }}=299.4\left[1-\mathrm{e}^{-0.0897507(t+6.55696)}\right]$, whereas for females it was $\mathrm{L}(\mathrm{t})_{\text {female }}=256.1\left[1-\mathrm{e}^{-0.23731(\mathrm{t}+3.01921)}\right]$. Individual growth curves obtained for males and females Amazonian manatees are shown in Figure 1 and Figure 2, respectively.

Based on the developed equations, the length at birth of Amazonian manatee was estimated at $133.2 \mathrm{~cm}(\mathrm{~min}=87.0 \mathrm{~cm}$, $\max =152.0 \mathrm{~cm}$, mean $=113 \mathrm{~cm}, \mathrm{sd}=34.4 \mathrm{~cm}$ ) for males, and $131.0 \mathrm{~cm}(\min =110.0 \mathrm{~cm}, \max =150.0 \mathrm{~cm}$, mean $=124.7 \mathrm{~cm}$, $\mathrm{sd}=22.0 \mathrm{~cm})$ for females. The annual growth rate $(\mathrm{k})$ obtained was $0.09 \mathrm{~cm}(\mathrm{CI} 95 \%: \pm 0.002)$, reaching a maximum curvilinear length of $299.0 \mathrm{~cm}$ (CI 95\%: \pm 2.039$)$ in males. Females presented an annual growth rate of $0.24 \mathrm{~cm}$ (CI 95\%: \pm 0.004$)$, reaching up to $256.1 \mathrm{~cm}$ (CI 95\%: \pm 0.4832) of curvilinear length.

Based on the estimated models, males Amazonian manatees reach their maximum curvilinear length at 79 years, where females reach their maximum length at 50 years.

\section{Discussion}

According to Rosas (1994), the curvilinear body length does not offer a good relationship with growth due to its variation with the animal's nutritional status. Therefore, one can expect an inherent error in the growth curves models presented in this study. Nevertheless, according to Colares (2002), the curvilinear body length is an important biological measurement to describe manatees' growth. Both authors conducted research with captive animals, a condition where the nutritional status is dependent on the food offered to the animals. For wild animals such as those studied here, the nutritional status will depend on the natural food availability. In Amazonia, food availability is related to the flood and drought seasons, and the nutritional status is also related to those seasons (Best 1983, Arraut 2008). Another factor to be considered is the origin of the information. Different from data evaluated by the authors cited above, data on the Amazonian manatees used in this study were obtained by local residents who, traditionally, use the ventral curvilinear length of culled animals as a measure standard. Considering that the curvilinear body length (ventral or dorsal) will never be less than the total rectilinear length of Amazonian manatees, and based on the results we found, we agree with Colares (2002) on the importance of this measurement to describe the species' growth.. We evaluate that a good relationship was obtained between this parameter and the estimated age, obtained by the application of von Bertalanffy's equation.

In his study, Colares (2002) observed, using Gompertz's and Brody's functions, that the curvilinear lengths estimated for adult captive Amazonian manatees were $214.93 \pm 2.42 \mathrm{~cm}$ for females and $216.53 \pm 1.52 \mathrm{~cm}$ for males. Those values were lower than the 


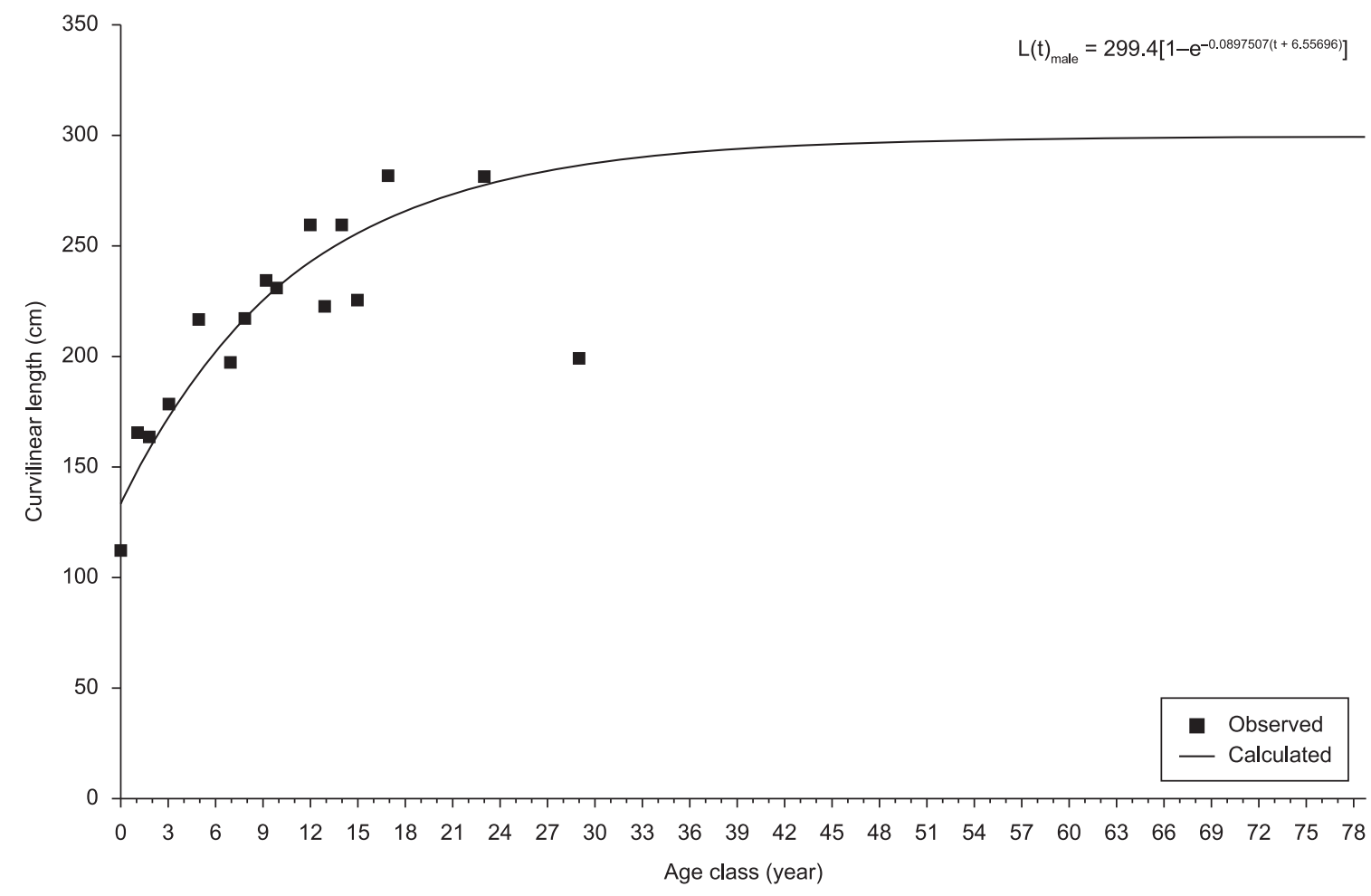

Figure 1. Growth curve, calculated by the von Bertalanffy's equation, of male Amazonian manatees captured between 1993 and 2006 by local residents of the mid-Solimões River and Pirativa River, Amazon region.

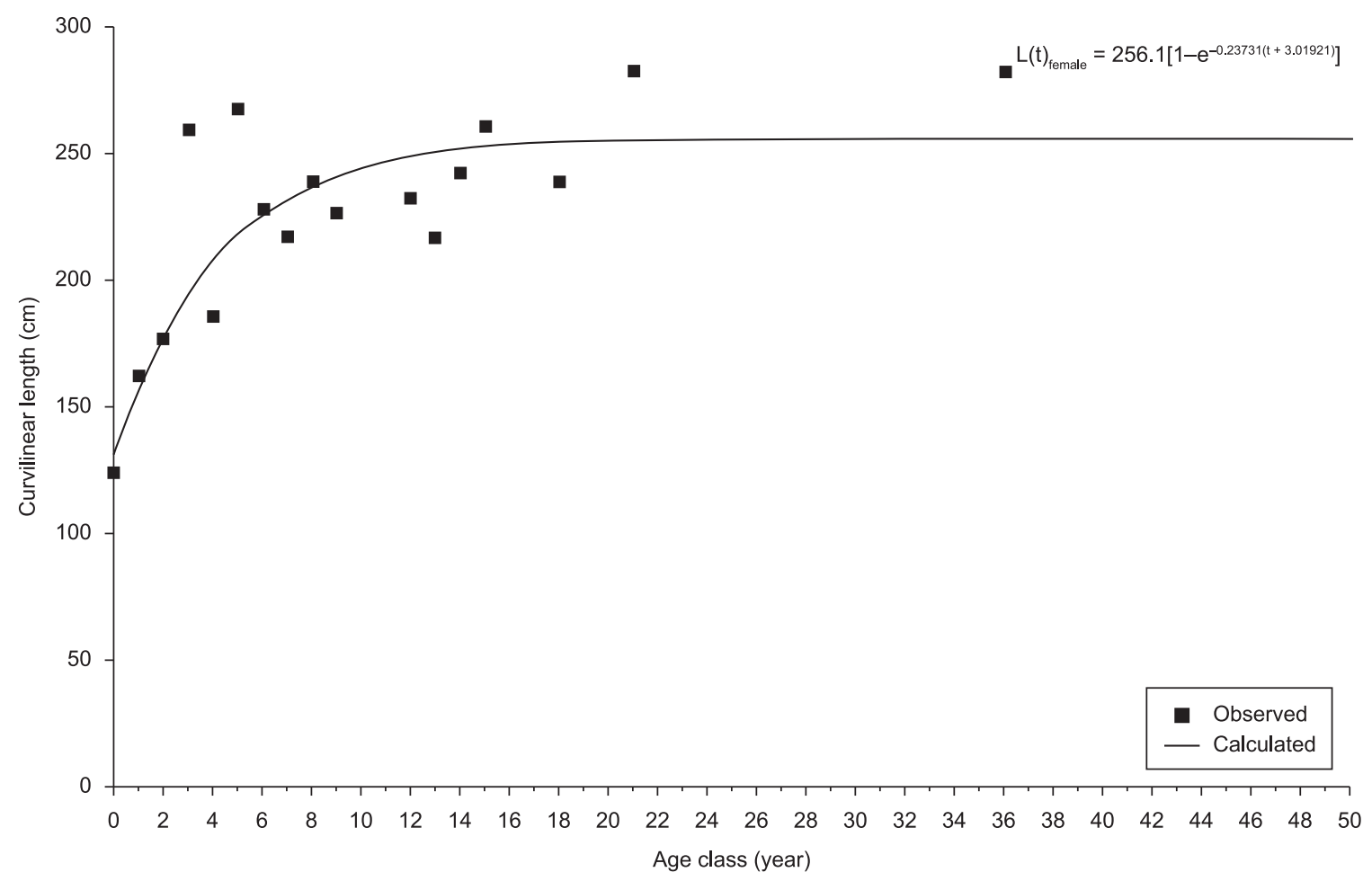

Figure 2. Growth curve, calculated by the von Bertalanffy's equation, of female Amazonian manatees captured between 1993 and 2006 by local residents of the mid-Solimões River and Pirativa River, Amazon region. 
ones observed in our study, for both females and males. The difference between our results and Colares' is due, probably, to the fact that specimens evaluated by the latter were captive and younger than those studied here. According to O'Regan \& Kitchener (2005) there are substantial differences related to body size and maturity rate between wild and captive animals, and this is mainly related to nutritional issues. The difference between the results suggest that the equations derived by Colares (2002) may not be applied to wild animals, whereas the estimated values of curvilinear length found in this study are compatible with body size of the species (Husar 1977). Moreover, the differences between males and females are similar to those found by Albuquerque Jr. (2003), with males being bigger than females.

The total body length of the Amazonian manatee birth ranges from 85 to $105 \mathrm{~cm}$ (D'Affonseca Neto \& Vergara-Parente 2006). The lowest values of curvilinear length we observed were equivalent to the results of body size previously described, although using von Bertalanffy's equation they were always larger than $130 \mathrm{~cm}$. The difference between the minimum lengths found with von Bertalanffy's equation in relation to those previously described in the literature is due to the small number of zero age specimens in the sample used to calculate the equation of this study, indicating the need to further studies.

Longevity of the Florida manatee (T. manatus latirostris) was estimated at over 60 years (Marmontel 1995), and maximum age for dugongs was estimated at 73 years (Marsh 1995). Although, the longevity for Amazonian manatees has not been defined yet, the oldest specimen analyzed had an age estimated at 36 years (Vergara-Parente, unpublished).

The individual growth rate $(k)$ is an important parameter to be considered in the study of species' growth. Value $k$ is the main parameter affecting the growth rate of a species. Albuquerque Jr. (2003) found $k$ values for captive Amazonian manatees of $0.21 \mathrm{~cm} /$ year and $0.33 \mathrm{~cm} /$ year for males and females, respectively. Although our results are different from those found by Albuquerque Jr. (2003), we also observed differences between growth rates among sexes, with females growing faster than males. This growth variation between sexes may be observed in other aquatic mammals (Boltnev et al. 1998, Barreto \& Rosas 2006) and is possibly related to the nursing of their young by females.

The lack of studies about growth equations for Amazonian manatees did not allow further comparisons with the results here obtained. Although widely used in growth studies of other aquatic mammals (Gol'din 2004, Barreto \& Rosas 2006, Branch 2008), von Bertalanffy's equation is not commonly used for sirenians and, when previously applied, had not presented satisfactory results (Colares 2002, Albuquerque Jr. 2003). Even though von Bertalanffy's equation proved adequate for the elaboration of a growth curve for Amazonian manatees, with results that agree with existing information on the biology of the species, further studies should be conducted with a larger number of specimens, including older age classes. The possible inherent errors in the growth equations resulting from the use of the body measuring method adopted by local residents (curvilinear length) also deserves to be better studied, so to provide robustness in the growth equation of the Amazonian manatee. As a suggestion, a new study on growth curves using specimens divided between capture time (flood and drought seasons) could provide a better adjustment to the von Bertalanffy's growth equation.

\section{Acknowledgements}

To Centro Mamíferos Aquáticos-CMA/ICMBio, Fundação Mamíferos Aquáticos and Mamirauá Institute for Sustainable Development, for the data on the animals. This work was conducted with financial support by Fundação de Amparo à Ciência e Tecnologia de Pernambuco-CAPES and Programa Beca-IEB/Moore Foundation (B/2005/02/BDP/02). This work was authorized by Instituto Brasileiro do Meio Ambiente e dos Recursos Naturais Renováveis (Ibama) under licence $\mathrm{N}^{\circ}$ 004-06/CMA/IBAMA - process IBAMA $\mathrm{N}^{\mathrm{o}} 0234.000061 / 05-10$.

\section{References}

ALBUQUERQUE Jr., D.P. 2003. Descrição histológica do tecido ósseo do domo timpânico, estimativa de idade e crescimento em cativeiro do peixeboi da Amazônia Trichechus inunguis (Natterer 1883) Mammalia, Sirenia. Dissertação de Mestrado, Universidade Federal do Amazonas, Manaus.

ARRAUT, E.M. 2008. Migração do peixe-boi amazônico: uma abordagem por sensoriamento remoto, radiotelemetria e geoprocessamento. Tese de Doutorado, Instituto Nacional de Pesquisas Espaciais, São José dos Campos.

BARRETO, A.S. \& ROSAS, F.C.W. 2006. Comparative growth analysis of two populations of Pontoporia blainvillei on the Brazilian coast. Mar. Mammal Sci. 22(3):644-653.

BEST, R.C. 1983. Apparent Dry-Season Fasting in Amazonian Manatees (Mammalia: Sirenia). Biotropica 15(1):61-64.

BEST, R.C., RIBEIRO, G.A., YAMAKOSHI, M. \& DA SILVA, V.M.F. 1982. Artificial feeding for unweaned Amazonian manatees. Int. Zoo Yearb. 22(1):263-267.

BOLTNEV, A.I., YORK, A.E. \& ANTONELIS, G.A. 1998. Northern fur seal young: interrelationships among birth size, growth, and survival. Can. J. Zoolog. 76:843-854.

BRANCH, T.A. 2008. Biological parameters for pygmy blue whales. In $60^{\text {th }}$ Annual Meeting the International Whaling Commission. Santiago. http:// iwcoffice.org/_documents/sci_com/SC60docs/SC-60-SH6.pdf

COLARES, F.A.P. 2002. Estudo de modelos não lineares de crescimento em peixe-boi marinho Trichechus manatus manatus e peixe-boi amazônico Trichechus inunguis (Mammalia:Sirenia) em cativeiro. Tese de Doutorado, Universidade Federal de Minas Gerais, Belo Horizonte.

COLARES, I.G. 1991. Hábitos alimentares do peixe-boi da Amazônia Trichechus inunguis (Mammalia:Sirenia). Dissertação de Mestrado, Instituto Nacional de Pesquisa da Amazônia, Manaus.

D'AFFONSECA NETO, J.A. \& VERGARA-PARENTE, J.E. 2006. Sirenia (peixe-boi-da-Amazônia, Peixe-boi-marinho). In Tratado de Animais Selvagens: medicina veterinária. (Z.S. Cubas, J.C.R. Silva \& J.L. CatãoDias, eds.). Roca, São Paulo, p. 701-714.

FITZHUGH Jr., H.A. 1976. Analysis of growth curves and strategies for altering their shapes. J. Anim. Sci. 42(4):1036-1051.

GOL'DIN, P.E. 2004. Growth and body size of the harbour porpoise, Phocoena phocoena (Cetacea, Phocoenidae), in the Sea of Azov and the Black Sea. Vestnik Zoologii 38(4):59-73.

HUSAR, S.L. 1977. Trichechus inunguis. Mamm. Species. 72:1-4.

Instituto Brasileiro do Meio Ambiente e dos Recursos Naturais Renováveis - IBAMA. 2001. Mamíferos aquáticos do Brasil: plano de ação. 2 ed. Brasília, DF, 102p.

IUCN. 2009. IUCN Red list of threatened species. Version 2009.2. http:// www.iucnredlist.org. (último acesso em 19/11/2009).

MARMONTEL, M. 1995. Age and reproduction in Female Florida Manatees. In Population Biology of the Florida Manatee. (T.J. O'Shea, B.B. Ackerman \& H.F. Percival, eds.) National Biological Service Information and Technology Report 1. p. 98-119.

MARMONTEL, M., O'SHEA, T.J. \& HUMPHREY, S.R. 1990. An Evaluation of Bone Growth-Layer Counts as an Age-Determination Technique in Florida Manatees. National Information Service, Springfield, VA, 104p. Document PB 91-103564.

MARSH, H. 1995. The life history, pattern of breeding, and population dynamics of the dugong. In Population Biology of the Florida Manatee. (T.J. O'Shea, B.B. Ackerman \& H.F. Percival, eds.) National Biological Service Information and Technology Report 1. p. 75-83.

O'REGAN, H.J. \& KITCHENER, A.C. 2005. The effects of captivity on the morphology of captive domesticated and feral mammals. Mammal. Rev. 35(3):215-230.

ROSAS, F.C.W. 1994. Biology, conservation and status of the Amazonian Manatee Trichechus inunguis. Mammal. Rev. 24:49-59. 